\title{
Faktor yang Berhubungan dengan Keikutsertaan PUS dalam Ber-KB
}

\author{
Hasanah Pratiwi Harahap* \\ Prodi D4 Kebidanan, Fakultas Farmasi dan Kesehatan, Institut Kesehatan Helvetia \\ *Email korespondensi: hasanah.hrp@gmail.com
}

\section{Article Info}

Article history:

Submitted: 2019-11-30

Accepted: $2019-12-19$

Published: 2019-12-30

Keywords:

Knowledge; Attitude; Culture; Family

Planning

ABSTRACT

Indonesia is a developing country that has a large population of about 237.6 million people and an average population growth rate of $1.49 \%$ per year. In Taraha Village, there are still many couples of reproductive age that are not acceptors, as many as $52(46.2 \%)$. The purpose of this study was to determine the factors associated with couples of reproductive age participation in the family planning program in Taraha Village in 2018. This research was analytic survey research with a cross-sectional approach. The data collection method used questioner. The study was conducted in Taraha Village, Mandrehe Utara Subdistrict, in 2018. The sample of this research was the productive age couples, who were 81 acceptors and not acceptors using a stratified random sampling technique. Data were analyzed by performing a Chi-square analysis test. Based on the results obtained on the knowledge variable the majority of knowledge lacking by 42 respondents (52\%) with a p-value $<0,001$, the majority of negative attitudes as many as 55 respondents $(68 \%)$ with a p-value of 0.010 , the majority of cultural factors were not good enough as many as 44 respondents (54\%) obtained a p-value $<0,001$. It is recommended to the government of Nias Barat District to increase health promotion, especially on the family planning program.

\section{ABSTRAK}

Kata kunci:

Pengetahuan;

Sikap; Budaya;

Keluarga

Berencana
Indonesia merupakan negara yang berkembang yang memiliki jumlah penduduk yang besar sebanyak 237,6 juta jiwa, dan laju pertumbuhan penduduknya rata-rata $1,49 \%$ per tahun. Di Desa Taraha masih banyak PUS yang bukan akseptor sebanyak 52 $(46,2 \%)$. Tujuan penelitian adalah untuk mengetahui faktor yang berhubungan dengan keikutsertaan PUS dalam ber-KB di Desa Taraha Kabupaten Nias Barat Tahun 2018. Penelitian ini merupakan penelitian survey analitik dengan pendekatan cross sectional. Metode pengumpulan data menggunakan kuesioner. Penelitian dilakukan di Desa Taraha Kecamatan Mandrehe Utara Tahun 2018. Sampel penelitian ini adalah Pasangan Usia Subur yang merupakan akseptor dan bukan akseptor sebanyak 81 PUS dengan teknik stratified random sampling. Data dianalisis dengan melakukan uji analisis Chi-square. Berdasarkan hasil penelitian diperoleh hasil pada variabel pengetahuan mayoritas pengetahuan kurang sebanyak 42 responden (52\%) dengan nilai $p$ value $<0,001$, pada sikap mayoritas sikap negatif sebanyak 55 responden $(68 \%)$ dengan nilai $p$ value 0,010 , pada faktor budaya mayoritas budaya kurang baik sebanyak 44 responden (54\%) diperoleh nilai $p<0,001$. Disarankan kepada instansi pemerintah terkait di Kabupaten Nias Barat untuk meningkatkan promosi kesehatan khususnya tentang KB. 


\section{PENDAHULUAN}

Masalah utama yang dihadapi di Indonesia adalah pengendalian tingkat kelahiran dan tingkat pertambahan penduduk yang demikian telah mempersulit usaha peningkatan dan pemerataan kesejahteraan rakyat. Indonesia merupakan negara yang berkembang yang memiliki jumlah penduduk yang besar. Pertumbuhan penduduk di Indonesia menimbulkan masalah yang serius di negara ini. Berdasarkan hasil sensus penduduk tahun 2010, jumlah penduduk Indonesia telah melampaui angka proyeksi nasional yaitu sebanyak 237,6 juta jiwa, dan laju pertumbuhan penduduknya rata-rata $1,49 \%$ per tahun. ${ }^{1}$

Menurut World Health Organization (WHO) 2014 penggunaan kontrasepsi telah meningkat dibanyak bagian dunia, terutama di Asia dan Amerika Latin dan terendah di Sub-Sahara Afrika. Secara global, pengguna kontrasepsi modern telah meningkat tidak signifikan dari 54\% pada tahun 1990 menjadi $57,4 \%$ pada tahun 2014. Secara regional, proporsi pasangan usia subur 15-49 tahun melaporkan penggunaan metode kontrasepsi modern telah meningkat minimal 6 tahun terakhir. Afrika dari 23,6\% menjadi $27,6 \%$, di Asia telah meningkat dari 60,9\%menjadi 61,6\%, sedangkan Amerika latin dan Karibia naik sedikit dari 66,7\% menjadi 67,0\%. Diperkirakan 225 juta perempuan di negara-negara berkembang ingin menunda atau menghentikan kesuburan tapi tidak menggunakan metode kontrasepsi apapun dengan alasan sebagai berikut: terbatas pilihan metode kontrasepsi danpengalaman efek samping. Kebutuhan yang belum terpenuhi untuk kontrasepsi masih terlalu tinggi. Ketidakadilan didorong oleh pertumbuhan populasi. ${ }^{2}$

Menurut Survey Demorafi Kesehatan Indonesia (SDKI) pada tahun 2017 persentase angka prevalensi pemakaian kontrasepsi yaitu pemakaian kontrasepsi berdasarkan provinsi tertinggi pada Yogyakarta (76\%) KB aktif dan terendah pada Papua $(38,4 \%)$ dan untuk Sumatera Utara $(67,4 \%)$ KB aktif dengan cakupan Indonesia sebesar $(63,6 \%)^{3}$

Berdasarkan Profil Dinas Pengendalian Penduduk dan Keluarga Berencana Kabupaten Nias Barat Tahun 2018 data PUS keseluruhan 11,283, dan peserta akseptor KB sebanyak 3.175 jiwa. Peserta KB aktif setiap Kecamatan terdiri dari: Kecamatan Moi sebanyak 13,5 \%, Kecamatan Mandrehe sebanyak 14,3\%, Kecamatan Mandrehe Utara sebanyak 10,0 \%, Kecamatan Moro'o sebanyak 5,6\%, Kecamatan Mandrehe Barat sebanyak 15,1\%, Kecamatan Sirombu sebanyak 12,2 \%, Kecamatan Ulumoro'o sebanyak 12,4 \%, Kecamatan Lakhomi sebanyak 16,4 $\%$.Target pencapaian pemakaian alat kontrsepsi di Nias Barat diharapkan 45\% PUS menggunakan KB. Kecamatan Mandrehe utara termasuk nomor 2 paling rendah menggunakan kontrasepsi dari delapan kecamatan. ${ }^{4}$

Peneliti melakukan survey awal dengan tanya jawab terhadap 5 PUS yang diantaranya memberikan pernyataan tidak ikut KB disebabkan budaya yang masih tinggi yaitu adanya budaya yang menyakini dengan cara keluarga berkumpul dan berdoa adalah cara PUS ber-KB yang mana setelah berdoa, mereka percaya bahwa tidak terjadi kehamilan kepada pasangan usia subur. Diketahui juga PUS kurang menyatakan tidak menggunakan KB karena berdampak negatif bagi mereka yang 
berasal dari efek samping alat kontrasepsi. Sikap PUS yang masih memberikan respon berupa penolakan ber-KB berupa dengan ber-KB akan mengurangi rezeki yang diterima karena PUS berasumsi bahwa semakin banyak anak maka akan semakin banyak rejeki yang harusnya didapat. Penelitian ini bertujuan untuk mengetahui dan menganalisis faktor yang berhubungan dengan keikutsertaan PUS dalam ber-KB di Desa Taraha Kecamatan Mandrehe Utara Kabupaten Nias Barat.

\section{METODE PENELITIAN}

Desain penelitian ini menggunakan survei analitik yaitu survei atau penelitian yang mencoba menggali bagaimana dan mengapa fenomena kesehatan itu terjadi. Rancangan pada penelitian ini adalah cross sectional, dimana penelitian dilakukan pada variabel bebas dan terikat bersamaan untuk mengetahui faktor yang berhubungan dengan keikutsertaan PUS dalam Ber-KB di Desa Taraha. Lokasi yang menjadi tempat penelitian adalah di Desa Taraha Kecamatan Mandrehe Utara tahun 2018, dan waktu yang diperlukan untuk penelitian ini adalah mulai bulan JanuariSeptember 2018

Populasi dalam penelitian ini adalah seluruh pasangan usia subur (PUS) di Desa Taraha dari Januari-September 2018 dengan 2 dusun sebanyak 102 PUS, dengan sampel berjumlah 81 PUS yang menggunakan rumus Slovin dan dan teknik stratified random sampling. Pengumpulan data menggunakan data primer dan sekunder. Teknik pengolahan data dalam penelitian ini meliputi collecting, cheking, coding, entering, data processing ${ }^{5}$. Analisis data berupa analisis univariat dan analisis bivariat yang menggunakan uji statistic chi-square dengan nilai $\alpha=0,05$.

\section{HASIL PENELITIAN}

\section{Analisis Univariat}

Tabel 1. Distribusi Frekuensi Responden Berdasarkan Pengetahuan, Sikap dan Budaya PUS di Desa Taraha

\begin{tabular}{lcc}
\hline \multicolumn{1}{c}{ Variabel } & f & \% \\
\hline Pengetahuan & & \\
Kurang & 42 & 52,0 \\
Baik & 39 & 48,0 \\
\hline Sikap & & \\
Negatif & 55 & 68,0 \\
Positif & 26 & 32,0 \\
\hline Budaya & & \\
Kurang baik & 44 & 54,0 \\
Baik & 37 & 46,0 \\
\hline
\end{tabular}

Hasil tabel 1. dapat diketahui bahwa distribusi frekuensi responden berdasarkan pengetahuan kurang sebanyak 42 orang (52\%), berdasarkan pengetahuan baik sebanyak 39 orang (48\%), dan distribusi frekuensi responden berdasarkan sikap yang negatif sebanyak 55 orang (68\%), berdasarkan sikap yang positif sebanyak 26 orang 
(32\%). distribusi frekuensi responden berdasarkan budaya yang kurang baik sebanyak 44 orang (54\%), berdasarkan budaya yang baik sebanyak 37 orang (46\%).

\section{Analisis Bivariat}

Tabel 2. Tabulasi Silang Hubungan Pengetahuan, Sikap dan Budaya dengan Keikutsertaan PUS dalam Ber-KB di Desa Taraha

\begin{tabular}{|c|c|c|c|c|c|c|c|}
\hline \multirow{3}{*}{ Variabel } & \multicolumn{4}{|c|}{ Keikutsertaan PUS dalam ber-KB } & \multirow{2}{*}{\multicolumn{2}{|c|}{ Total }} & \multirow{3}{*}{ Nilai $p$} \\
\hline & \multicolumn{2}{|c|}{ Bukan Akseptor } & \multicolumn{2}{|c|}{ Akseptor } & & & \\
\hline & $\mathbf{n}$ & $\%$ & $\mathbf{n}$ & $\%$ & $\mathbf{n}$ & $\%$ & \\
\hline \multicolumn{8}{|l|}{ Pengetahuan } \\
\hline Kurang & 26 & 32,1 & 16 & 19,8 & 42 & 51,9 & $<0,001$ \\
\hline Baik & 26 & 32,1 & 13 & 16,0 & 39 & 48,1 & \\
\hline \multicolumn{8}{|l|}{ Sikap } \\
\hline Negatif & 41 & 50,6 & 14 & 17,3 & 55 & 67,9 & 0,010 \\
\hline Positif & 11 & 13,6 & 15 & 18,5 & 26 & 32,1 & \\
\hline \multicolumn{8}{|l|}{ Budaya } \\
\hline Kurang baik & 37 & 45,7 & 7 & 8,6 & 44 & 54,3 & $<0,001$ \\
\hline Baik & 15 & 18,5 & 22 & 27,3 & 37 & 45,7 & \\
\hline
\end{tabular}

Hasil tabel 2. diketahui bahwa mayoritas PUS berpengetahuan kurang sebanyak 42 responden $(51,9 \%)$ dimana 26 responden $(32,1 \%)$ bukan akseptor dan 16 responden (19,8\%) akseptor. Hasil uji statistik diperoleh nilai $p$ adalah $<0,001$ yang menyatakan ada hubungan pengetahuan dengan keikutsertaan PUS dalam ber-KB di Desa Taraha. Berdasarkan 81 responden mayoritas sikap PUS termasuk negatif sebanyak 55 responden $(67,9 \%)$ yang mana 41 responden $(50,6 \%)$ bukan akseptor dan 14 responden $(17,3 \%)$ akseptor. Hasil uji statistik diperoleh $p$ value adalah 0,010 sehingga diketahui ada ada hubungan yang signifikan antara sikap dengan keikutsertaan PUS dalam ber-KB di Desa Taraha. Budaya PUS masyoritas termasuk kategori kurang baik sebanyak 44 responden (54,3\%) diantaranya 37 responden $(45,7 \%)$ bukan akseptor dan 7 responden $(8,6 \%)$ akseptor. Hasil uji statistik diperoleh nilai $p$ adalah $0,001<0,05$ yang berarti ada hubungan budaya dengan keikutsertaan PUS dalam ber-KB di Desa Taraha.

\section{PEMBAHASAN}

\section{Hubungan Pengetahuan dengan Keikutsertaan PUS dalam Ber-KB}

Hasil penelian ini sesuai dengan penelitian yang dilakukan oleh Ahmad Nasurulloh (2015) di wilayah kerja puskesmas purwosari kota surakarta, hasil analisis chi square pengetahuan $(p=0.01)$ sikap $(0,03)$, dukungan keluarga $(p=0,016)$, dapat disimpulkan bahwa ada hubungan antara pengetahuan, sikap, dan dukungan keluarga dengan keikutsertaan pasangan usia subur (PUS). Pengetahuan atau kognitif merupakan domain yang sangat penting dalam membentuk tindakan seeorang. Pengetahuan tentang KB merupakan salah satu aspek penting kearah pemahaman terhadap pentingnya peran serta suami dan istri dalam program KB dan dapat 
berpengaruh terhadap perilaku suami dan istri untuk berperan serta dalam program $\mathrm{KB}^{6}$.

Berdasarkan teori W.J.S Poerwordaminto Pengetahuan merupakan suatu hal yang sangat dibutuhkan dalam rangka perubahan pola pikir dan perilaku suatu kelompok dan masyarakat. Pengetahuan ini terkait dengan lingkungan dimana seseorang menetap. Keadaan lingkungan sekitar sedikitnya akan mempengaruhi pengetahuan dalam hal ini pengetahuan mengenai kontrasepsi jangka panjang. Pengetahuan yang masyarakat diperoleh dari hasil belajar, berkomunikasi dengan orang lain, media elektronik, media cetak dan pengalaman. Pengetahuannya yang menunjang program KB yaitu pengetahuannya yang lebih tinggi sangat berpengaruh dalam mengambil keputusan untuk kesehatannya. ${ }^{7}$

Menurut asumsi peneliti terhadap hubungan pengetahuan dengan keikutertaan PUS dalam ber-KB merupakan faktor yang menentukan PUS dalam ikut ber-KB. Banyak PUS yang berpengetahuan kurang dapat dilihat dari jawaban responden yang mengatakan karena banyak PUS tidak mengetahui bahwa keluarga berencana adalah mengatur jumlah, jarak dan usia ideal melahirkan anak, dan Sasaran KB adalah PUS yang bertujuan untuk menurunkan tingkat kelahiran dengan cara penggunaan kontrasepsi secara berkelanjutan. PUS hanya banyak mengetahui bahwa keluarga berencana merupakan salah satu program pengendalian penduduk,ini sebabkan karena kurangnya sumber informasi yang didapatkan, serta kurangnya promosi kesehatan dari pemerintah yang terkait. Faktor lain pengetahuan PUS dalam ber-KB disebabkan karena sikap PUS yang mengatakan bahwa menggunakan KB dapat membuat sering pusing yang merupakan efek samping dari alat kontrasepsi tersebut seperti alat kontrasepsi suntuk 3 bulan. Faktor lain juga di sebabkan karna kurangnya dukungan suami terhadap istri dalam ber-KB, di sebabkan juga karena faktor pekerjaan serta tempat pelayanan kesehatan yang jauh. PUS yang memiliki pengetahuan kurang baik tetapi menjadi akseptor KB disebabkan karena pengaruh dari kader dan juga teman yang sudah menggunakan akseptor KB.

Studi sebelumnya menunjukkan bahwa penerimaan anak sebagai kehendak Tuhan, sikap terhadap pencegahan kehamilan, pengetahuan tentang pilihan metode yang berbeda dan pemahaman tentang efek samping dari metode yang berbeda adalah diantara faktor yang berkaitan dengan penggunaan kontrasepsi. ${ }^{8,9}$

\section{Hubungan Sikap dengan Keikutsertaan PUS dalam Ber-KB}

Hasil penelian ini sesuai dengan penelitian yang dilakukan oleh Ahmad Nasurulloh (2015) di wilayah kerja puskesmas purwosari kota surakarta, hasil analisis chi square pengetahuan $(p=0.01)$ sikap $(0,03)$, dukungan keluarga $(p=0,016)$, dapat disimpulkan bahwa ada hubungan antara pengetahuan, sikap, dan dukungan keluarga dengan keikutsertaan pasangan usia subur (PUS). Sikap seseorang dipengaruhi oleh aspek pengetahuan yang berisikan aspek positif dan negatif dari suatu hal. Bila orang melihat program KB lebih banyak aspek yang positif dari pada aspek yang negatif, dan aspek yang positif itu lebih penting dari aspek yang negatif, maka akan tumbuh sikap yang positif terhadap program KB. Sebaliknya apabila seseorang melihat program KB lebih banyak aspek negatifnya dibandingkan aspek positif, maka sikap negatiflah yang 
akan muncul. Dari analisis di atas dapat ditarik kesimpulan bahwa tingginya angka keikutsertaan KB disebabkan karena tingginya tingkat pengetahuan responden mengenai program KB sehingga menimbulkan tumbuhnya sikap positif responden untuk ikut berpartisipasi dalam program KB. ${ }^{6}$

Hal sesuai dengan teori penelitian yang dilakukan Surhayat mengatakan sikap adalah perbuatan yang didasari oleh keyakinan berdasarkan norma-norma yang ada di masyarakat dan biasanya norma agama. Namun demikian perbuatan yang akan dilakukan manusia biasanya tergantung apa permasalahannya serta benar-benar berdasarkan keyakinan atau kepercayaannya masing-masing. ${ }^{10}$

Menurut asumsi peneliti terhadap hubungan sikap dengan keikutsertaan PUS dalam ber-KB, sikap positif merupakan faktor yang menentukan PUS alam menggunakan kontrasepsi, PUS yang sikap positif terhadap kontrasepsi banyak yang berminat untuk menggunakan atau menjadi akseptor KB, tetapi masih ada PUS yang sikap positif tidak menggunakan KB disebabkan karena pengetahuan yang masih kurang, budaya yang di anut dan juga karena kurangnya dukungan suami yang tidak menginginkan istrinya untuk ber-KB. Sikap negatif juga merupakan faktor PUS untuk menggunakan kontrasepsi, tetapi PUS yang sikap negatif menjadi akseptor KB disebabkan karena pengaruh terhadap PUS yang lain yang menggunakan kontrasepsi. Sifat sikap dapat pula bersifat positif dan pula bersifat negatif.

Penelitian Mustafa, et al memberikan wawasan ke dalam konteks lokal terkait dengan pengetahuan, sikap, persepsi, dan praktik keluarga berencana dan juga menyoroti perlunya kontrasepsi, terutama untuk kontrasepsi jangka panjang dan kontrasepsi. Setelah perubahan sikap terhadap keluarga berencana dan ukuran keluarga yang diinginkan, lebih banyak wanita dan pasangan akan mencari layanan keluarga berencana. Mengatasi hambatan seperti akses, keterjangkauan, dan ketersediaan akan membantu memenuhi kebutuhan ini dan memastikan bahwa perempuan dan pasangan dapat memenuhi tujuan melahirkan dan kesehatan reproduksi mereka. Selain itu, persepsi kebutuhan kontrasepsi yang sangat rendah ditemukan di antara responden yang menginginkan lebih banyak anak. ${ }^{11}$

\section{Hubungan Budaya dengan Keikutsertaan PUS dalam Ber-KB}

Hal ini sesuai dengan penelitian yang dilakukan oleh Cindi Naomi Tobing terdapat pengaruh yang signifikan antara faktor peran lingkungan sosial (nilai $p=$ $0,0001<\alpha$ ) terhadap PUS menjadi akseptor KB dari faktor yang terbentuk. Disimpulkan bahwa faktor peran lingkungan sosial memiliki pengaruh yang signifikan terhadap PUS menjadi akseptor KB di Wilayah Kerja Puskesmas Simpang Limun Kota Medan tahun $2018 .{ }^{12}$

Hal ini sesuai dengan teori Prawirohardjo yang mengatakan budaya adalah suatu cara hidup yang berkembang, dan dimiliki bersama oleh sebuah kelompok orang, diwariskan dari generasi ke generasi. Budaya berbentuk dari unsur rumit, termasuk sistem agama, dan politik, adat istiadat, bahasa, perkakas, pakaian, bangunan, dan karya seni. Budaya adalah suatu pola hidup menyeluruh. Budaya bersifat kompleks, abstrak, dan luas. Banyak aspek budaya turut menentukan perilaku komunikatif 
Sejumlah faktor budaya dapat mempengaruhi klien dalam memilih metode kontrasepsi. Faktor ini meliputi salah pengertian dalam masyarakat mengenai berbagai metode, kepercayaan religius, serta budaya, tingkat pendidikan persepsi mengenai risiko kehamilan dan status wanita., Penyedia layanan harus menyadari bagaimana faktor tersebut mempengaruhi pemilihan metode di daerah mereka dan harus memantau perubahan yang mungkin mempengaruhi pemilihan metode. ${ }^{13}$

Menurut asumsi peneliti terhadap budaya dengan keikutsertaan PUS dalam ber$\mathrm{KB}$, budaya kurang baik merupakan faktor penyebab PUS tidak ikut ber-KB, tetapi masih ada PUS budaya kurang baik menjadi akseptor KB disebabkan karena sebagian PUS tidak percaya terhadap budaya yang dianut,serta memiliki pengetahuan yang baik. PUS yang budaya baik merupakan faktor penyebab PUS ikut dalam ber-KB, tetapi masih ada PUS yang bukan akseptor KB disebabkan karena mengikuti budaya yang dianut yang mengatakan bahwa KB dilarang oleh agama serta sikap terhadap Kontrasepsi skurang baik dengan mengatakan menggunakan KB dapat membuat sering pusingdan juga karena kurangnya dukungan suami yang tidak mengizinkan istri untuk ber-KB disebabkan karena belum mendapatkan anak dengan jenis kelamin lakilaki.ber-KB. Selain itu perlu juga mendorong laki-laki untuk ber-KB. Partisipasi pria dalam program KB khususnya penggunaan alat kontrasepsi masih sangat rendah. Keengganan pria berkontrasepsi banyak disebabkan faktor persepsi umum yang menyatakan bahwa KB adalah urusan wanita dengan kodratnya untuk hamil dan melahirkan, terlebih lagi mayoritas masyarakat kita adalah partiakri. ${ }^{14}$ Selain itu, studi tentang persepsi persetujuan suami secara positif terkait dengan penggunaan kontrasepsi yang rendah. ${ }^{15,16}$

\section{SIMPULAN DAN SARAN}

Faktor Pengetahuan, Sikap dan budaya berhubungan dengan keikutsertaan PUS dalam ber-KB di Desa Taraha Kecamatan Mandrehe Utara Kabupaten Nias Barat. Diharapkan kepada Bagi Desa Taraha di harapkan kepada PLKB (penyuluh lapangan KB) untuk selalu memberikan informasi dan konseling kepada PUS, serta untuk mengubah pola pikir penduduk desa, tentang faktor yang berhubungan dengan keikutsertaan PUS dalam ber-KB sehingga program KB dapat tercapai.

\section{UCAPAN TERIMA KASIH}

Terimakasih peneliti ucapkan kepada PUS yang telah memberikan izin serta sarana dan prasarana selama pelaksanaan penelitian, sehingga penelitian berjalan dengan lancar.

\section{DAFTAR PUSTAKA}

1. Pratiwi ED, Sariyati S. Agama dengan Keikutsertaan Keluarga Berencana (KB) dan Pemilihan Jenis Alat Kontrasepsi pada Pasangan Usia Subur (PUS) di Desa Argomulyo Sedayu Bantul Yogyakarta Religion in Family Planning Participation and Contraceptives Selection of. 2015;1-9.

2. Kuswandari TD. Perbedaan Pengetahuan Sebelum dan Sesudah Pemberian Pendidikan dengan Metode Snowball Throwing tentang Kontrasepsi Hormonal pada 
Pasangan Usia Subur Non Akseptor KB di Pucangan Puskesmas Kartasura Kabupaten Sukoharjo. [Skripsi]. Universitas Muhammadiyah Surakarta; 2015.

3. BKKBN. Infomasi Kependudukan, KB dan Pembangunan Keluarga. J Kel. 2018;4.

4. BKKBN. Berdasarkan profil Dinas Pengendalian Penduduk dan Keluarga Berencana Kabupaten Nias Barat. 2018.

5. Muhammad I. Panduan Penyusunan Karya Tulis IImiah Bidang Kesehatan Menggunakan Metode IImiah Hal 92-98. Bandung: Citapustaka Media Perintis; 2016.

6. Nasrulloh A. Hubungan antara Pengetahuan, Sikap, dan Dukungan Keluarga dengan Keikutsertaan Pasangan Usia Subur (PUS) dalam Ber-KB di Wilayah Kerja Puskesmas Purwosari Kota Surakarta. [Skripsi]. Universitas Muhammadiyah Surakarta; 2015.

7. Prawirohardjo S. Faktor-Faktor yang Mempengaruhi Program KB Ilmu Kebidanan. Jakarta: Bina Pustaka; 2016.

8. Speizer IS, Irani L, Barden-O'Fallon J, Levy J. Inconsistent fertility motivations and Contraceptive use Behaviors among Women in Honduras. Reprod Health [Internet]. 2009 Dec 19;6(1):19. Available from: https://reproductive-healthjournal.biomedcentral.com/articles/10.1186/1742-4755-6-19

9. Tilahun T, Coene G, Luchters S, Kassahun W, Leye E, Temmerman M, et al. Family Planning Knowledge, Attitude and Practice among Married Couples in Jimma Zone, Ethiopia. Baradaran HR, editor. PLoS One [Internet]. 2013 Apr 23;8(4):e61335.

Available from: https://dx.plos.org/10.1371/journal.pone.0061335

10. Suharyat Y. Hubungan antara Sikap, Minat dan Perilaku Manusia. J Reg. 2009;1(3).

11. Mustafa G, Azmat SK, Hameed W, Ali S, Ishaque M, Hussain W, et al. Family Planning Knowledge, Attitudes, and Practices among Married Men and Women in Rural Areas of Pakistan: Findings from a Qualitative Need Assessment Study. Int J Reprod Med [Internet]. 2015;2015:1-8. Available from: http://www.hindawi.com/journals/ijrmed/2015/190520/

12. Tobing CN. Penerapan Analisis Komponen Utama untuk Mengidentifikasi FaktorFaktor yang Memengaruhi Pasangan Usia Subur (PUS) Menjadi Akseptor KB di Wilayah Kerja Puskesmas Simpang Limun Kota Medan Tahun 2018. [Skripsi]. Univesitas Sumatera Utara; 2018.

13. Nuryani S. Beberapa Faktor yang Berhubungan dengan Pengambilan Keputusan dalam Keluarga Berencana pada Kelompok Ibu di Wilayah Puskesmas I Sukoharjo. [Skripsi]. Universitas Muhammadiyah Surakarta; 2009.

14. Ramadhan K. Faktor Yang Berhubungan dengan Keikutsertaan Peserta KB Metode Operasi Pria (MOP) di Kecamatan Kontunaga Kabupaten Muna. J Publ Kesehat Masy Indones [Internet]. 2015;2(3):132-41. Available from: https://ppjp.ulm.ac.id/journal/index.php/JPKMl/article/view/2728

15. A K. Husband-wife Agreement, Power Relations and Contraceptive Use in Turkey. Int Fam Plan Perspect. 2008;34(3).

16. Kartikasari B, Nurhaeni IDA, Adriani RB. Path Analysis on the Social, Economic, and Cultural Determinants of Male Contraceptive Use in Family Planning Village, Yogyakarta, Indonesia. Indones J Med [Internet]. 2018;3(2):89-98. Available from: http://theijmed.com/index.php?journal=theijmed\&page=article\&op=view\&path $\% 5 \mathrm{~B} \%$ $5 \mathrm{D}=129 \&$ path $\% 5 \mathrm{~B} \% 5 \mathrm{D}=81$ 